Transcontinentales

continentales

Sociétés, idéologies, système mondial

\title{
Afrique du Nord, Moyen-Orient
}

\section{(2) OpenEdition \\ 1 Journals}

Édition électronique

URL : http://journals.openedition.org/transcontinentales/1436

DOI : 10.4000/transcontinentales. 1436

ISBN : 978-2-8218-1410-3

ISSN : $1775-397 X$

Éditeur

Editions de la maison des sciences de l'homme

Édition imprimée

Date de publication : 31 décembre 2005

Pagination : 157

ISBN : 2200-92168-3

ISSN : $1950-1684$

\section{Référence électronique}

"Afrique du Nord, Moyen-Orient », Transcontinentales [En ligne], 1 | 2005, document 25, mis en ligne le , consulté le 25 septembre 2020. URL : http://journals.openedition.org/transcontinentales/1436 ; DOI : https://doi.org/10.4000/transcontinentales.1436

Ce document a été généré automatiquement le 25 septembre 2020.

Tous droits réservés 


\section{Afrique du Nord, Moyen-Orient}

1 Éditions, 2004, 532 p. 
15 LATTE ABDALlAH Stéphanie (dir.), Images aux frontières. Représentations en conflit et constructions sociales et politiques. Palestine, Jordanie 1948-2000, Damas, IFPO, 2005, $369 \mathrm{p}$.

16 PLIEZ Olivier (dir.), La nouvelle Lybie. Sociétés, espaces et géopolitique au lendemain de l'embargo, Le Caire, CÉDÉJ, 2004, 238 p.

17 SARTRE-FAURIAT Annie, Les voyages dans le Hawran (Syrie du sud) de William John Bankes (1816 et 1818), Bordeaux, Ausonius éditions/Beyrouth, IFPO, 2004, 352 p.

18 WEISS Leopold, Florence HEYMANN (traduit et annoté par), Un Proche-Orient sans romantisme. Journal de voyage, Paris, CNRS Éditions, 2004, 162 p. 